Анета Тривић

Универзитет у Крагујевцу

Филолошко-уметнички факултет
811.163.6'373.7; 811.134.2'373.7

https://doi.org/10.18485/filkult.2016.1.ch9

\title{
КУЛТУРОЛОШКА УСЛОВЉЕНОСТ СОМАТСКЕ ФРАЗЕОЛОГИЈЕ СРПСКОГ И ШПАНСКОГ ЈЕЗИКА
}

\section{Сажетак}

Фразеолошке неподударности у међујезичким истраживањима приписују се лингвистичким, али и екстралингвистичким факторима, попут културолошких и социолошких. Будући да су фразеологизми унутар својих говорних заједница препознати као носиоци историјских, националних, социолошких и других традиционалних вредности, на међујезичком плану разлике међу њима доминирају када је реч о културолошки обојеним јединицама које су типичне за говор одређеног етноса, и које се, у зависности од обичаја и веровања, везују управо за тај народ (Пирајнен 2008, Боерс 2008, Добровољски 2000, Анхелова Ненкова 2007, Корпас Пастор 2000, Мршевић-Радовић 2008). Такве су фразеолошке јединице из сфере фламенка или борбе с биковима у шпанском језику, које именују појаве и обичаје који не постоје у српској традицији.

Предмет овог истраживања су семантичке неподударности код соматских или корпоралних фразеологизама српског и шпанског језика. Соматски фразеологизми нису у великој мери условљени културолошким феноменима и очигледно настају на основу универзалних метафоричких преноса базираних на човековом телесном искуству. Резултати истраживања показују да се међу њима најређе остварује однос семантичке неподударности и на корпусу од готово деветсто фразеологизама издвојено је тек неколико десетина примера (cabeza de turco, coger entre ojos (a alguien), en el ojo del huracán, главом и брадом, ни за живу главу). Закључци недвосмислено упућују да телесно, физичко искуство представља основу за вербализацију и разумевање (углавном апстрактних) појава и односа, као и да је корпоралност, телесност, предуслов и оријентир за њихову даљу дескрипцију и категоризацију. Дискрепанце у концептуализацијама на плану соматске фразеологије српског и шпанског језика резултат су прожимања универзалних али и специфичних, локално обојених пресликавања.

Кључне речи: Соматска фразеологија, српски, шпански, преводна еквиваленција, семантичка неподударност, појмовна метафора. 


\title{
1. Увод.
}

Фразеологија је онај слој језичка једног народа који је у најужој вези с културом, обичајима и традицијом тог етноса, а фразеологизми „крију мноштво слика о друштвеним, историјским, културним и другим променама једне заједнице" (Пејовић 2015: 169). Она је такође изразито интердисциплинарна област, која се карактерише и као „експанзионистичка”, зато што „залази како у друге лингвистичке дисциплине (на првом месту лексикологију и семантику, али и синтаксу и творбу) тако и нелингвистичке дисциплине (културологију, антропологију, психолохију, социологију)" (Драгићевић 2010: 8).

Предмет овог истраживања су семантичке неподударности или дискрепанце код соматских или корпоралних фразеологизама српског и шпанског језика. У раду испитујемо како се из угла контрастивне лингвитике различите перцепције концептуализују кроз наше телесно искуство. Анализирамо и упоређујемо ове врсте концептуализација из лингвокултуролошког у когнитивнолингвистичког угла, и управо те области представљају теоријску основу истраживања. Лингвокултурологија је део етнолингвистике који на синхроном нивоу истражује везу између језика и културе, бави се

\begin{abstract}
„живим комуникационим процесима и везом између језика и менталитета народа (...). За свој предмет истраживања има безеквивалентну лексику у једном језику и лексичке празнине, као и митологизоване језичке јединице, паремиолошки и фразеолошки језички слој, еталоне, стереотипе итд. ".
\end{abstract}

(Драгићевић 2010: 9)

Анализу спроводимо и у теоријским оквирима когнитивне лингвистике, тачније теорије појмовне метафоре, које истичу важност физичког и чулног искуства за схватање и разумевање света који нас окружује и односа који се у њему успостављају (Lakoff, Johnson 1980, Johnson 1990, Iñesta Mena, Pamies Bertrán 2002, Klikovac 2004, Dobrovol'skiĭ 2005, Mršević-Radović 2008, Kövecses 2010, Dragićević 2010, Mellado Blanco 2012). Когнитивна лингвистика изразито је интердисциплинарна област, зато што интегрише лингвистику, психологију и 
филозофију, антропологију, а анализу језика изједначава с анализом мишљења. На језик гледа као на један површински део целокупне човекове когнитивне способности и психолошке организације, а не као на аутономну способност. Језичка компетенција зависи од свеукупног когнитивног и сензомоторног развоја, од меморије, перцепције и искуства уопште. То значи да су сви когнитивни процеси исти, а ту спадају и они који управљају употребом језика, те се стога језик може адекватно моделирати коришћењем општих концептуалних структура и когнитивних способности (Крофт, Круз 2004: 1).

Можемо рећи да се ово истраживање базира на тачки пресека између лингвокултуролошке и когнитивнолингвистичке анализе. Методолошки оквири унутар којих оперишему јесу концептуална и контрастивна анализа. Настојимо да разумемо и објаснимо етимологију контрастираних израза, али и да кроз илустративне примере представимо њихову употребу у савременим језичким формама. Корпус смо формирали на идиоматским изразима локализованим у постојећим општим (DRAE 2001, DUE 2002, PMC/MX 1967-76, PMC 2007) и фразеолошким једнојезичним речницима (DFDEA 2004, DFEM 1997, Matešić 1982, Otašević 2012).

\section{2. Телесна условљеност концептуализација}

Централни појам когнитивне лингвистике јесте ментална концептуализација. Она се донекле изједначава с појмом значење, а оба именују образовање појмова на основу човековог физичког, чулног, емоционалног и интелектуалног искуства са светом који га окружуje (Klikovac 2004: 9). На човека и околни свет не гледа се као на две одвојене категорије, које функционишу независно једна од друге. Људска когниција и телесно искуство међусобно се преплићу и условљавају, људска стварност обликована је човековим телесним искуством, а искуство је уткано у његову спознају стварности. Џонсон (1990) се залаже за „повратак тела у ум“ када уочава да је наше телесно искуство (положај тела, покрети, просторна и временска оријентација) оно што нам омогућава да разумемо свет и околину, да их организујемо и класификујемо, и да се снађемо у њима. Он 
уводи појам сликовних шема (image schemata) које су засноване на искуству и интегрални су део значења, и без којих би наше искуство било неорганизовано и нејасно (Џонсон 1990: хіv).

Ментална концептуализација зависна је, дакле, од скупа искустава и доживљаја света сваког појединца. Апстрактне и сложене појаве разумемо на основу искустава из нашег окружења и оне директно произилазе из наше непрестане интеракције с физичким окружењем. У том смислу се метафорички изрази базирани на деловима људског тела генеришу у процесима метафоричког пресликавања између изворног домена - у овом случају људског тела и различитих циљних концептуалних домена, попут апстрактних појава, емоција, тренутних физичких стања и других сложених феномена. Они су директно условљени нашим физичким искуством и перцепцијом.

У когнитивнолингвистичком окружењу људско тело се узима као најважнији изворни домен у процесима творбе израза с идиоматским, пренесеним значењем и у конструисању сложених феномена уопште. У односу на остале изворне домене (нпр. животиње, биљке, здравље и болести, грађевине и конструкције, машине и оруђа) оно предњачи по фреквентности употребе (Кӧvecses 2010: 18) и постаје основно средство за објашњење метафоре и когнитивносазнајних механизама. Заправо је окарактерисано као идеални изворни домен зато што је исто код свих и зато што га веома добро познајемо (Кövecses 2010: 18). Оваква антропоцентрична визија лако може да објасни сличне концептуализације у различитим културама у језицима ${ }^{1}$. Људско тело, његови делови, положај у простору одсликавају нашу концептуализацију, разумевање емоција, објеката, феномена. Делови тела представљају срж човековог поимања света, појава и дешавања у њему, човекових рекција и вредновања других

1 Наредни примери израза из српског језика имају своје формалне и семантичке еквиваленте у шпанском језику. Они илуструју како у различитим језицима и културама исти делови људског тела могу послужити као изворни домени у метафоричким пресликавањима којима се исказују исти аптрактни циљни домени. Оваква пресликавања се означавају као универзална, и за разлику од културолошки условљених пресликавања која су предмет нашег истраживања, универзална пресликавања нису локално, специфично надограђена (бити (нечија) десна рука $(\rightarrow$ циљни домен ПОМоЋ, ПРИЈАТЕљСтво), срце проблема ( $\rightarrow$ циљнИ домен СУштИНА, СРж), платити главом ( $\rightarrow$ циљни домен СМРТ), сачувати (живу) главу ( $\rightarrow$ циљни домен ЖивОТ), имати чисте руке/ бити чистих руку (циљни домен МОРАЛ, ИСПРАВНОСТ), у трен ока/док оком тренеш ( $\rightarrow$ циљни домен ТЕМПОРАЛност)). 
људи и догађаја који га окружују. Човек и његово тело су као кантар, мерило за оцењивање околног света, отуда изражена антропометричност језика. Управо соматски фразеологизми указују на значајну улогу коју у језику имају метафоре базиране на телесности (human embodiment) и телесном искуству (bodily experience).

\section{3. Културолошка условљеност концептуализација}

Ипак, у оквирима когнитивне лингвистике одређење појма искуство, а самим тим и когниција, спознаја, језик проширује се и не везује само за искуства физичке природе која су условљена непосредним, чулним опажањима. Прихвата се да искуство има и ширу компоненту, да се одвија на широкој позадини одређених културних претпоставки и да је условљено друштвеном и културолошком стварношћу. Увелико је уврежено мишљење да су метафоричка пресликавања у непосредној вези, односно да проистичу из социјалног искуства појединца. Поред непосредног физичког окружења и шире окружење (култура, традиција, веровања, друштво) неодвојиви су део људског бића и као такви инкорпорирани у његов животни развој, у сазнајне процесе попут мишљења, меморије или говора. Отуда когнитивна теорија метафоре проширује свој опсег и прихвата да метафоре и концептуализације проистичу из одређеног контекста у смислу да их говорник интерпретира кроз сопствено тумачење засновано на индивидуалним (физичким и менталним), али и друштвеним и културолошким искуствима (Лангакер 2001: 145).

У међујезичким истраживањима управо се екстралингвистички фактори, попут културолошких и социолошких, узимају за основни узрок фразеолошких неподударности. Овакаво уверење није изненађујуће, када знамо да су фразеологизми унутар својих говорних заједница препознати као носиоци историјских, националних, социолошких и других традиционалних вредности. На међујезичком плану разлике међу њима доминирају када је реч о културолошки обојеним јединицама које су типичне за говор одређеног етноса, и које се, у зависности од обичаја и веровања, везују управо за тај народ (Пирајнен 2008, Боерс 2008, Добровољски 2000, Анхелова Ненкова 2007, Корпас Пастор 2000, Мршевић-Радовић 2008). 
Преводна еквиваленцији или сличности значења један је од основних појмова којима оперише контрастивна лингвистика, а посебно контрастивна анализа. Предмет интересовања у овом раду су изрази који творе однос тзв. нулте еквиваленције или апсолутне неподударности, који настаје када фразеолошка јединица из изворног језика (L1) нема свој еквивалент у другом, циљном језику (L2) и не може бити преведена другом таквом јединицом. Заправо се ради о својеврсном језичком анизоморфизму (или одсуству језичког изморфизма), када се језичке реалије из L1 не концептуализују, а самим тим и не лексикализују у L2 из лингвистичких, културних или историјских разлога (Корпас Пастор 2003: 217, 227). Најчешће су у питању специфичности одређених језика и заједница које су културолошки условљене, а саме јединице рефлектују неки идиосинкратички аспект културе из које потичу и у којима су присутни национални елементи, називи за културно обојене појмове. Такве су фразеолошке јединице из сфере борбе с биковима или фламенка у шпанском језику, које именују појаве и обичаје који не постоје у српској традицији. „Ову врсту односа илуструју јединице које карактерише висок степен социокултурне мотивације, и чији настанак и употреба корелирају са неком специфичном екстралингвистичком ситуацијом" (Анхелова Ненкова 2006: 106). Разлике, дакле, доминирају тамо где је реч о фраземима типичним за говор одређеног етноса који се, у зависности од обичаја, веровања, везују управо за тај народ. Када се приближимо заједничком, европском миљеу, те разлике се умањују (Корпас Пастор 2003). Овакав апсолутно асиметричан однос између јединица два језика узрокује појаву тзв. фрразеолошких празнина или лакуна. (шп. lagunas fraseológicas)

\section{4. Метафоричке неподударности у пресликавањима на плану српских и шпанских соматизама}

Анализа сематичких дискрепанци на плану српског и шпанског језика део је ширег истраживања, које је показало да су соматски фразеологизми једно од најпродуктивнијих и најфреквентнијих језичких поља. Обрађени корпус на којем је вршен паралелан опис 
српских и шпанских фразема обухватио је око девет стотина израза и потврдио њихов изузетан творбени, семантички и фраземотворни потенцијал. Анализа је вршена двосмерно, те су и српски и шпански представљали и полазни и циљни језик (Тривић 2015 b). Када је реч о утврђивању степена семантичке и формалне преводне еквиваленције показало је да се тај распон креће од апсолутног поклапања до потпуног непоклапања, при чему се најчешће остварује однос (делимичне или потпуне) подударности. Најређе се остварује однос неподударности, односно нулте преводне еквиваленције и за ову прилику смо издвојили свега неколико десетина примера који илуструју ову врсту односа.

Нагласили смо већ да се фразеолошке неподударности углавном приписују екстралингвистичким факторима. Како је реч о садржајима и концептима који се вербално не испољавају у циљном језику, преводилачки поступак не може укључити супституцију, најпожељнији преводилачки поступак, већ се прибегава различитим процедурама попут описивања, парафразирања и других техника трансференције. Једино је тако могуће пренети значење, али се при томе губе сва остала конотативна и експресивна обележја. Када на одабраном корпусу упоредимо фразеолошке системе шпанског и српског језика, уочавамо да се ова врста еквиваленције реализује у најмањем проценту, што нас наводи на закључак да соматски фразеологизми нису у великој мери условљени културолошким феноменима као и да очигледно настају на основу универзалних метафоричких преноса базираних на човековом телесном искуству. Семантичке и концептуалне неподударности се уочавају тек код неколико десетина примера (escarmentar en cabeza ajena, cabeza de turco, en el ojo del huracán, tener mucho ојо, главом и брадом, ни за живу главу, morderse (alguien) las manos, (пре)крстити се левом и десном руком, бити на своју руку, по dar su/el brazo a torcer, untar(le) la(s) mano(s) a alguien, no es nada lo del ojo, en el ojo del huracán). Ови изрази немају своје преводне еквиваленте на плану ова два језика и, иако телесно мотивисани, не настају на основу универзалних, већ специфичних културолошких пресликавања, која су традиционално, историјски, социокултурно мотивисана. Изрази рефлектују различите идиосинкратичке аспекте српске и шпанске културе и у њима доминирају национални елементи и симболи. 
Лексеме глава и cabeza (шп. глава) генеришу неколицину израза који су специфични за своје говорне заједнице. Изрази по dejar / quedar títere con cabeza (досл. 'не оставити / није остала лутка / марионета с главом') $)^{2}$ негативно су конотирани и припадају домену деструкције и страдања. Означавају „уништити, повредити, докусурити". Они воде порекло из традиције луткарског позоришта (los teatrillos de títeres, de guiñol, de marionetas), конкретније, из начина на који су се луткарске представе завршавале. Обичај је био да на крају сваке представе избије општа туча између лутки или марионета, које су обавезно остајале обезглављене, на општу радост својих најмлађих посматрача, деце (DDFH).

(1) El Comité de Empresa del Liceo ha elaborado un duro informe (sobre la crítica situación del Liceo) en el que no deja títere con cabeza. (Управни одбор школе је начинио извештај (о критичној ситуацији у школи), у којем нико није остао поштеђен.) (rae.es 10.07.2014)

У метафоричкој позадини ових варијанти је слика света према којој постоје судбинске нити којима смо сви међусобно повезани, а којима управља нека виша сила. Нит симболише „људски усуд, судбину, коју испреда и тка божанска моћ" (RS). Слично пресликавање постоји у луткарским представама када на сцени луткар управља марионетом „повлачећи конце по својој вољи“, што је, према МршевићРадовић, мотивисало изразе „држати све конце у својим рукама („управљати чиме”), повући, повлачити конце („повући потезе, доносити одлуке о чему"), помрсити конце (коме) (покварити рачуне, посао, наудити коме)" (Мршевић-Радовић 2009: 366). ${ }^{3}$

2 Títere је појам из луткарског позоришта којим се означава марионета, дрвена лутка која се покреће помоћу конца или жице, или платнена, крпена лутка која се навлачи на руку.

3 Слична пресликавања базирана на лексемама нит, конац уочавамо и код других фразеологизама српског и шпанског језика, који именују различите концептуалне домене: ВЛАст, контолА Или ГУБИтАК влАстИ, контроЛЕ (држати / узети / имати конце у својим рукама, (ис)пустити конце / нити... из (својих) руку / шака), сМрТ, НЕпоСРЕДНА ОПАСНОСТ (глава (некоме) виси о / на концу / власи, la cabeza pende de un hilo (досл. 'глава виси о концу'). 


\section{Филологија културе}

У шпанском језику конструкција cabeza de turco (досл. 'глава Турчина') симболише особу на коју се сваљује кривица, без јасног разлога и доказа. Он је, дакле, једини одговорни и главни кривац. У српском језику му одговарају изрази (бити) дежурни кривац, (бити) жртвени јарац. Води порекло из времена других крсташких ратова, када су често вођене борбе између Шпанаца и Турака и из којих су остала усмена предања о тим борбама. Према њима је највећу част за борца представљало одсецање главе турским ратницима, који су сматрани кривцима за многе недаће шпанског народа. Израз је остао актуелан и у савременом језику представља веома експресивно језичко средство.

(2) Los negros - continúa - hemos sido siempre la cabeza de turco de todos los problemas de Estados Unidos. (Ми црнци - наставља - увек смо били једини одговорни за све проблеме у Сједињеним Државама.) (rae.es 11.09.2012)

Варијанте aprender / escarmentar / experimentar (...) en cabeza ajena (досл. 'научити (се) / учити / осетити ... на туђој глави') именују семантички садржај „извући поуку (из туђег искуства, примера)”. И са̂м глагол escarmentar својеврстан је спецификум шпанског језика и његово примарно значење састоји се из неколико семема, означава „(на)учити на туђим грешкама”. Како израз нема формални еквивалент у српском језику преводимо га неком од идиоматских конструкција другачије метафоричке основе (учити на туђим грешкама или научити се памети).

(3) Parece que el chico ha escarmentado en cabeza ajena, porque después del accidente que sufrió su amigo ya no quiere saber nada de la motocicleta. (Чини се да је момак извукао поуку, јер након удеса који је доживео његов друг, више неће ни да чује за мотор) (DFEM)

У српском језику се конструкције мућнути / мућкати / (про) дрмнути / (про)дрмати главом, протрести главу користе да именују идеју промишљања и разборитости. Означавају „дубље, 
боље размислити”, „мозгати” (PMC/MX) и маркиране су као неформалне. Шпански језик не познаје адекватан формални еквивалент, те их преносимо описно: pensarlo bien ('добро размислити'). У основи израза је метафоричко пресликавање ГлАВА JE ПосуДА / СПРЕМИШТЕ. У облицима мућнути / мућкати главом та посуда садржи течност и треба је (про)мућкати како би се садржај (течност) разбистрио. Овде је квалификатор бистро изворни домен за ЈАСНо, РАзУМно (уп. бистар ум), док је замућено изворни домен за НЕJACHO, НЕРАЗУМно (УП. замућен ум, мутно је (коме) у глави).

У облицима дрмнути главом, протрести / продрмати главу глава је посуда коју повремено треба продрмати како би се њен садржај (мисли, идеје) адекватно сложиле.

(4) (Коментар:) Тај који је то говорио требало би добро да мућне главом какве је поруке слао ономе који је имао командну одговорност. (politika.rs 15.11.2009)

Изрази српског језика дунуло / дошло / ударило му (јој...) је у главу припадају домену неразумног понашања и означавају „помислити нешто ненадно и необично”, „одједном се одлучити за нешто” (PMC/MX), „истерати свој хир”.

(5) Pre četrdeset i kusur godina bio je poznat u Nišu kao velika nada bokserskog kluba „Radnički» i juniorski šampion Jugoslavije Onda mu je nešto „dunulo u glavu» i krenuo je u avanturu osvajanja Evrope, ne bi li bolje unovčio svoje mišiće. (glas-javnosti.rs 12.09.2001)

Д. Мршевић-Радовић (2008) указује да су за мотивацију ових, али и свих других фразеологизама који директно или индиректно садрже семантичку компоненту ветар, релевантне физичке карактеристике ветра као стихије или природне силе. У варијанти дунуло му (јој...) је у главу лексема ветар није именована, али је семантички повезана с глаголом дунути / дувати, те се подразумева да је некоме ветар дунуо у главу. Ово значење („неразумно понашање”) у складу је са симболиком ветра, према којој је он „симбол испразности, непостојаности, несталности" (РС). 
Сличну улогу у српском језику ветар има и у творби других израза различите семантике: имати дивљи (луди) ветар у глави означава "бити срдит, љутит”, „помахнитати од љутине”, као и „бити веома узнемирен". Израз је мотивисан сликом брзог и снажног ветра који се неконтролисано креће кроз главу и описује одређено човеково ментално или емотивно стање. Д. Мршевић-Радовић (2008: 107) указује да

„није случајно што се баш ветар сматрао одговорним за човеково ментално и душевно здравље. Познато је из искуства да осетљиве особе и нервни болесници теже подносе промене и дување јаких ветрова, посебно јужних. Лоше расположење или погоршање здравља у таквим околностима могло се схватити и као узроковано самим ветром, а обично се манифестовало главобољом и нервном растројеношћу“. (Мршевић-Радовић 2008: 107-108). ${ }^{4}$

За српски језик карактеристични су и фразеологизми из концептуалног домена муке, невоље: (о)бити се / разби(ja)mи / (о)лупати се о главу (некоме нешто). Њима се имплицира да неко испашта, да трпи последице својих поступака, да ће га сустићи невоље. Намера је да се пренесе опомена, претња, упозорење да ће на некога пасти одговорност за нешто, да ће „1. сносити последице нечега, испашта због тога, свети му се (...) 2. сноси одговорност, одговоран је за нешто" (PMC/MX). Изрази су мотивисани перцепцијом тикве као синонима за шупљу, празну главу, а идеја да се тикве свакоме лупају о главу доживљава се као упозорење да је свако бити одговоран за своје поступке, што је основна поука народне пословице ко с ђаволом тикве сади, о главу му се лупају / обијају (Мршевић-Радовић 2008).

4 Шпански језик не твори сличне појмовне обрасце у којима се ветар сматра узрочником неразумног понашања. Идиоматски изрази базирани на слици ветра одсликавају га као брзу и моћну силу, као препреку или повољност за остварење неког циља: como el viento (досл. 'као ветар', „брзо”), contra viento y marea (досл. 'против ветра и плиме', „одлучност да се нешто спроведе упркос свим препрекама”), correr malos vientos (досл. 'трче / дувају лоши ветрови', „неповољне и лоше околности”), Ilevarse el viento una cosa (досл. 'ветар је нешто однео', „нестало је” или „узалуд се потроши ло, проћердало се”), (publicar) a los cuatro vientos (досл. '(објавити) на четири ветра)', „разгласити свуда и свима”) ,(ir) viento en popa (досл. 'ветар у крму', „(иде) успешно, без проблема") (DUE). 
(6) Kopredsednik Igmanske inicijative Aleksandar Popov kaže da su se barikade na severu Kosova "obile o glavu" Srbiji. (b92. net 09.12.2011)

Лексеме око и ојо (шп. око) такође реко учествују у творби фразеологизама који на плану српског и шпанског језика немају адекватне формалне и семантичке еквиваленте. У шпанском језику је у најширој употреби израз tener mucho ојо (досл. 'имати много ока') којим се појединац описује као домишљат, способан и лукав. Овај фразеолошки карактеризатор односи се на квалитете когнитивне природе и мотивисан је универзално присутном метафором видетИ JE ЗНАТИ. Нема преводни еквивалент у српском језику, већ га преносимо описно, помоћу атрибута (мудар, лукав, промућуран, кликераш) или помоћу идиоматске конструкције сличног значења, имати кликер (за нешто). ${ }^{5}$

(7) Para dirigir un negocio tan arriesgado como éste hace falta gente que tenga mucho ojo y no se deje engañar fácilmente. (Да би се водио један тако ризичан посао какав је овај, потребни су промућурни људи које није лако насамарити.) (DFEM)

Конструкција a ojo de buen cubero (досл. 'оком доброг бачвара') означава да се нека радња врши одока, „отприлике, без тачне мере” (DFDEA). Функционише као дескриптор околносног оквира и реферише о начину вршења радње, али и о количини и о квалитету нечега. Етимологија израза упућује на један обичај из прошлости, када није постојао некакав објективан, прецизан начин за мерење количине течности (попут воде, уља, вина). Потрошачи су се тада ослањали на слободну - најчешће добру - процену бачвара и крчмара (који су брижљиво чували бачве са драгоценим садржајем) и слободним оком, без помоћних средстава, вршили процену (DDFH).

5 Шпански језик познаје формално истоветне изразе tener / andar con mucho ојо (досл. 'имати / ићи са много ока', „добро пазити, бити обазрив"), imucho ојо! (досл. 'много ока ', "пажња"), који не именују појаве интелектуалне природе, већ појаве из домена опреза, пажње. Они функционишу као говорни чин упозорења („(добро) пази“). 


\section{Филологија културе}

(8) Un estudio comparativo de consultas (....) constató que incluso el mejor buscador realiza sus cálculos a ojo de buen cubero. (Једна упоредна студија интернет претраживања (...) показала је да чак и најбољи претраживачи врше прорачуне одока). (bbc.co.uk 20.02.2012)

У оба језика лексеме око и ојо помоћу фразеологизама базираним на зоонимима и на основу универзално присутних поређења именују добар, изоштрен вид, нпр. око соколово и ојо de águila (досл. 'око орла'). Поред тога, шпански језик, специфично, метафоризује ово значење на бази поређења са другом животињом - рисом: tener ojos / vista de lince (досл. 'имати око / вид риса'). Ова метафора заснована је на специфичном културолошком моделу на основу којег рис (lince) има одређену фолклорну или митолошку улогу. Рис је, наиме, добио име по изразито сјајним очима, и ова животиња симболише светлост, а верује се да га треба гледати у очи кад год се за тим укаже прилика. Такође је симбол тајновитости и мистериозности и према предању његов вид је толико добар да може да види кроз објекте (DS).

(9) Para ser piloto de aviación hay que tener ojos de lince; una persona que necesita gafas, como tú, no tiene nada que hacer en aviación. (За пилота у авијацији је неоходно да има изузетно добар вид; неко коме требају наочаре, као ти, нема шта да тражи у авијацији.) (DFEM)

Уочено је да у контрастираним језицима идиоматски изрази с компонентама око и ојо често илуструју негативно конотиране особине човека. Тако се у српском језику за незајажљивог и незаситог човека може рећи да има велике очи (у њега су велике очи) или да има гладне очи (очи су му гладне). Ова друга варијанта у свом примарном значењу припада домену хране, зато што именује некога ко је изјелица, гурман и прождрљивац. То примарно значење је проширено на домен грамзивости и незаситости, па тако можемо чути да су некоме очи гладне пара (славе / моћи итд.). Израз је мотивисан метафором ЖЕљА ЈЕ ГЛАД, „која се заснива на метонимијској вези између човекових потреба - једне типичне физиолошке и једне типичне емо- 
ционалне”, а у њима очи „преузимају функцију органа за варење: уста и желуца" (Милановић 2014: 389).

(10) (коментар:) Vidiš kakve su mu oči ( - političarima - ), gladne para, nikad dosta. (vesti-online.com 08.07.2011)

Ове идиоматске изразе у шпански језик, преносимо описно, придевима insaciable („незасит"), codicioso („похлепан”). У шпанском језику се концепти грамзивости, похлепе, изразите жеље за нечим везују за домен пића, односно жеђи (la sed de riqueza / fama / poder..., досл. 'жеђ за богатсвом / славом / моћи..'), на основу универзалне метафоре ЖЕљА ЈЕ ПИЋЕ / ХРАНА.

Веома је занимљива и употреба шпанске конструкције по es nada lo del ојо (досл. 'није ништа с оком') која се користи као коментар да се умањи значај и озбиљност неке потенцијално опасне појаве, која се на овај начин предстаља као мање опасна или као неважна. Овај израз нема еквивалент у српском језику и преводимо га описно „није ништа страшно”, „није тако озбиљно”. DDFH наводи пун облик no es nada lo del ojo y lo llevaba en la mano (досл. 'није ништа с оком и носио га је ( имао га је у руци')), који је први пут забележен на почетку XVIII века. Његово настанак се везује за немили догађај током којег је један од тореадора у току борбе с биковима (corrida de toros) изгубио око, након чега је почео да трчи наоколо носећи око у руци и узвикујући іNo es nada, no es nada! (Huje нuшта, није ништа!) како би умирио публику.

Лексему brazo (срп. рука) у шпанском језику карактерише изразито низак творбени потенцијал када је реч о генерисању идиоматских израза. Она, ипак, твори један веома стари израз, својствен искључиво говорницима ове заједнице. Облик по dar su brazo a torcer (досл. 'не дати руци да буде оборена / савијена') актуелан је и у савремном језику и концептуализује идеју тврдоглавости. Описује човека који не одступа од својих уверења и не мења мишљење. Израз води порекло из једне игре, популарне у прошлости, у којој су мушкарци обарали руке. Мотивисан је сликом такмичара који ни по коју цену не допушта противнику да га победи тако што ће допустити да му овај оборити руку. 


\section{Филологија културе}

(11) Es ... caudillo que defiende su causa y sus ideas contra todo y por sobre todo. No da el brazo a torcer. (Он је... вођа који брани своја начела и идеје пред свима и по сваку цену. Не попушта.) (rae.es 14.05.2013)

У шпанском језику постоје варијанте untar(le) la(s) mano(s) a alguien (досл. 'подмазати / намазати некоме шаку / шаке'). Њихова веома сликовита метафоричка основа помаже у тумачењу значења „подмитити, поткупити”. Српски језик не познаје преводни еквивалент који би био формално и значењски истоветан.

(12) En este pueblo fronterizo se hacía contrabando sin riesgo alguno; bastaba con untarle las manos a los funcionarios de aduanas. (У овом пограничном селу увек се могло шверцовати без икаквог ризика; довољно би било подмитити царинике.) (DFEM)

Овом анализом нисмо детаљно представили неколицину преосталих израза који испољавају неподударности на семантичком плану српског и шпанског језика. Међу карактеризаторима радњи и појава издвајају се изрази с адвербијалном функцијом: ни за живу главу, који преноси идеју степена вероватноће или пробабилности остварења неке радње и одређује је као неоствариву; на лепе очи који служи као дескриптор радњи које се обављају лако, без муке и труда; (costar / valer / cobrar...) un ojo de la cara (досл. '(коштати / вредети / наплатити...) колико / као око из лица') квалификују радњу или појаву као прескупу; en el ojo del huracán (досл. 'у оку/центру урагана') означава „бити у жижи дешавања”, „у центру збивања, па чак и скандала". У српском језику се још издвајају конструкције бити на своју руку (за опис појединца као чудака, особењака), иде од руке (некоме нешто) за онога ко „неки посао обавља без тешкоћа, са успехом” (PMC/MX), крстити се левом и десном руком која припада домену чуђења, неверице. 


\section{5. Закључак}

Закључци који се могу извести указују да је човеково телесно, физичко искуство једно од најважнијих полазишта или изворних домена у процесима творбе израза с идиоматским, пренесеним значењем и конструисања сложених феномена уопште. Оно представља предуслов и оријентир за њихову вербализацију, дескрипцију, разумевање и категоризацију. Дискрепанце у концептуализацијама на плану соматске фразеологије српског и шпанског језика резултат су прожимања универзалних али и специфичних, локално обојених пресликавања. Резултати истраживања недвосмислено показују да се међу соматским фразеологизмима српског и шпанског језика најређе остварује однос семантичке неподударности. Закључак је такав зато што соматски фразеологизми углавном не корелирају са неком екстралингвистичком ситуацијом специфичном за један етнос, већ са пресликавањима насталим на основу људског тела које је универзално и исто код свих.

Концептуалне и семантичке соматске неподударности на плану српског и шпанског језика резултат су надоградње ових универзалних пресликавања оним специфичним, локално обојеним. Иако присутне у малом броју оне сведоче да културно и друштвено условљене претпоставке, поред физичког искуства и перцепције, чине неодвојиви део људског искуства. Културолошки и традиционално обојени изрази који су опстали у употреби до данашњих дана право су богатство зато што сведоче о некадашњим вредностима, обичајима и веровањима. Иако их соматски изрази вероватно најмање подржавају од свих осталих лексичко-семантичких групација унутар фразеологије, ово истраживање мали је допринос њиховом очувању и истицању њихових вредности.

\section{Извори}

CREA: Real Academia Española: Banco de datos, Corpus de Referencia del Español Actual. (http://www.rae.es)

DDFH: Buitrago, Alberto. Diccionario de dichos y frases hechas. Espasa, 2000.

DFDEA: Seco de Arpe, Manuel. Diccionario fraseológico documentado del español actual: locuciones y modismos españoles. Aguilar, 2005. 


\section{Филологија културе}

DFEM: Varela, Fernando, \& Hugo Kubarth. Diccionario fraseológico del español moderno. Gredos, 1996.

DS: Chevalier, Jean et. al. Diccionario de los símbolos. Herder, 1986.

DLVEE: Penadés Martínez, Inmaculada. Diccionario de locuciones verbales para la enseñanza del español. Arco Libros, 2002.

DLNAPEE: Penadés Martínez, Inmaculada. Diccionario de locuciones nominales, adjetivas y pronominales para la enseñanza del español. Arco Libros, 2008.

DUE: Moliner, María. Diccionario de uso del español, I-II, Gredos, 2002.

RS: Gerbran, Alen, \& Ševalije, Žan. Rečnik simbola: mitovi, snovi, običaji, postupci, oblici, likovi, boje, brojevi. Stilos art Kiša, 2009.

PMC: Речник српскога језика. Матица српска, 2007.

PMC/MX: Речник српскохрватскога књижевног језика, I-VI. Матица српска, Матица хрватска, 1967-1976.

\section{Библиографија}

Ángelova Nénkova. "Factores socioculturales para la formación de las unidades fraseológicas." Interculturalidad y lenguaje. El significado como colorario cultural, edited by Luque Durán, Juan D. \& Antonio Pamies Bertrán, A. Granada Lingvistica, 2007, 165-172.

Corpas Pastor, Gloria. "Acerca de la (in)traducibilidad de la fraseología." Las lenguas de

Europa: Estudios de fraseología, fraseografía y traducción, edited by Gloria Corpas Pastor. Comares, 2000, pp.483-523.

Corpas Pastor, Gloria. Diez años de investigación en fraseología: Análisis sintáctico-semánticos, contrastivos y traductológicos. Lingüística Iberoamericana, 2003.

Croft, William \& D. Alan Cruse. Cognitive Linguistics.Cambridge University Press, 2004.

Dobrovol'skij, Dmitrij. "Idioms in contrast: a functional view." Las lenguas de Europa: Estudios de fraseología, fraseografía y traducción, edited by Gloria Corpas Pastor, Comares, 2000, 367-388.

Драгићевић, Рајна. Вербалне асоцијације кроз српски језик и културу. Чигоја, 2010.

Ibarretxe-Antuano, Iraide. "La lingüística cognitiva y su lugar en la historia de la lingüística." Revista Española de Lingüística Aplicada 26, 2013, 245-266.

Iñesta Mena, Eva María, \&Antonio Pamies Bertrán. Fraseología y metáfora: aspectos tipológicos y cognitivos. Método, 2002.

Johnson, Mark. The Body in the Mind. The Bodily Basis of Meaning, Imagination, and Reason, University of Chicago Press, 1990.

Klikovac, Duška. Metafore u mišljenju i jeziku. XX vek, 2004.

Kövecses, Zoltán. Metaphor. A Practical Introduction. Oxford University Press, 2010.

Lakoff, George \& Mark Johnson. Metaphors we live by. University of Chicago Press, 2003.

Langacker, Ronald. "Discourse in Cognitive Grammar", Cognitive linguistics 12-2, 2001, 143-188.

Милановић, Светлана. „Фразеологизми с компонентом око: универзално и специфично." Научни састанак слависта у Вукове дане, 43/1, МСЦ, 2014, 385-393. 
Мршевић-Радовић, Драгана. Фразеологија и национална култура. Друштво за српски језик и књижевност Србије, 2008.

Palmer, Gary. "When does cognitive linguistics become cultural?" Cognitive Linguistics Investigations edited by June Luchjenbroers, John Benjamins, 2006, pp. 13-47.

Пејовић, Анђелка. Контрастивна фразеологија шпанског и српског језика. ФИЛУМ, 2015.

Penadés Martínez, Inmaculada. "Análisis cognitivo de locuciones somáticas nominales del español, catalán y portugués." El valor de la diversidad (meta)lingüística, edited by Antonio Moreno Sandoval, 2008, pp. 1586-1607.

Толстој, Никита Иљич. Језик словенске културе. Просвета, 1995.

Тривић, Анета. „Фраземи с компоненатама рука и тапо као карактеризатори човека у српском и шпанском језику." Зборник Матице српске за филологију и лингвистику, LVIII-2, 2015(а), pp. 191-204..

Тривић, Анета. Лексичко-семантичка анализа соматизама у фразеологији савременог шпанског и српског језика: контрастивни приступ. Универзитет у Крагујевцу (необјављена докторска дисертација), 2015 (b).

\section{Aneta Trivić}

University of Kragujevac

Faculty of Philology and Arts

\section{Culturological motivation of somatic phraseology in Serbian and Spanish}

\section{Summary}

Phraseological discrepancies within cross-linguistic investigations are attributed to linguistic and extralinguistic factors, such are culturological and sociological. Since phraseologisms are recognized as bearers of historical, national, sociological and other traditional values within specific communities, the differencies between them in crosslinguistic studies are predominant when cultural aspects of phraseological units become manifest, due to its' interdependence on speech of specific ethnos (Piirainen 2008, Boers 2008, Dobrovol"skiĭ 2000, Angelova Nenkova 2007, Corpas Pastor 2000, Mršević-Radović 2008). Phraseologisms related to flamenco or bullfighting traditions in Spanish language provide good example, as they are not in any way present in Serbian language and folklore.

In this paper we address semantic discrepancies in somatic, corporal or bodyreferred idioms in Serbian and Spanish. Somatic idioms are generally not motivated by 
culturological phenomena and are generated by universal metaphorical mappings based on human body and experience. The analysis made on corpus of nearly nine hundred phraseological result result in only few dozen examples of semantic inconsistencies, and show that in somatic phraseology the relation of semantic incompatibility is by far the rarest (cabeza de turco, coger entre ojos (a alguien), en el ojo del huracán, главом и брадом, ни за живу главу).

These conclusions clearly indicate that corporal, physical experience represents the foundation for verbalization and understanding of Summary relations and phenomenon, and that corporeality is basic condition for their further description and classification. Discrepancies in conceptualizations in Serbian and Spanish somatic phraseology are understood as the result of symbiosis of universal and specific, locally colored mappings.

Key words: Somatic phraseology, Serbian, Spanish, semantic discrepancy, translation equivalence, conceptual metaphor. 